\title{
Dari Masa Lalu ke Masa Kini: Memori Kolektif, Konstruksi Negara dan Normalisasi Anti-Komunis
}

\author{
Hardiyanti Munsi \\ Departemen Antropologi, Fisip-Unhas \\ hardiyantimunsi@gmail.com
}

\begin{abstract}
This article is focused on how the incident of G30S/PKI has left atrauma to the state and how the state deals with it in the era afterwards. It show that such incident is constructed by the state that PKI is the enemy of the state and threathens the sovereignity of the state ideology, and this is embedded to shape a collective memory. This has been used to construct and to normalize the anti-communist movement in Indonesia through various strategies by, for example, the establishment of Monumen Pancasila Sakti, the suppression of communist movement, the military recruitment, and a variety of doctrines in the military education. These aim to construct a united understanding about the incident of G30S/PKI and to normalize the anti-communist discourse in Indonesia.
\end{abstract}

Keywords: Collective memory, PKI, G30S/PKI, TNI, state, construction, anti-communist, normalization.

\section{Pendahuluan}

Peristiwa bersejarah yang menimpa bangsa Indonesia pada tahun 1965 yang dikenal dengan istilah Gerakan 30 September/Partai Komunis Indonesia (G30S/PKI) memang telah hampir setengah abad yang lalu. Peristiwa yang melibatkan dua kubu (TNI dan PKI) bahkan seluruh komponen negara dan menarik perhatian secara nasional dan internasional. Peristiwa ini dipicu oleh penculikan dan pembunuhan 6 Jendral oleh kelompok yang menyebut diri mereka 'Gerakan 30 September'. Propaganda militer mulai disebarkan, dan menyerukan 'pembersihan' PKI di seluruh negeri. Propaganda ini berhasil meyakinkan rakyat Indonesia dan pemerhati internasional bahwa dalang di balik semua peristiwa itu adalah PKI. Penyangkalan PKI sama sekali tidak berpengaruh sehingga PKI dinyatakan sebagai partai terlarang. Ketegangan dan kebencian yang terpendam selama bertahuntahun pun meledak. 'Pembersihan' dilakukan dengan memusnahkan seluruh simpatisan PKI, termasuk Soekarno (yang pada saat itu dipaksa untuk menyerahkan kepemimpinan karena diduga sebagai pendukung PKI), pembakaran markas PKI, dan pembentukan kelompok pemuda yang anti-komunis.

Menurut Herlambang (2013), upaya pemberantasan bangkitnya komunisme di segala lini kehidupan terus dilakukan oleh pemerintah Orde Baru dimana Suharto berperan sebagai otak dari rencana ini. Pemberantasan komunisme secara sistematis dan represif telah dilakukan selama 32 tahun, antara lain, dengan menetapkan peraturan perundang-undangan yang ditujukan bagi para eks-tahanan politik (eks-tapol). Sedikitnya 30 butir undang-undang ini memang terutama sekali berlaku bagi seluruh anggota PKI dan ormas yang bernaung dibawahnya. Bukan hanya itu, perlakuan yang sangat menyakitkan juga harus dirasakan orang-orang yang tidak ada sangkutpautnya dengan PKI. Ada peraturan 'surat bebas G30S' bagi orang-orang yang akan bersekolah dan melamar pekerjaan, melampirkan surat pernyataan 'bersih diri' dan 'lingkungan' bagi orang yang memiliki sanak-saudara yang diduga atau dituduh dekat dengan PKI atau organisasi kiri, bahkan melarang anak keturunan PKI menjadi anggota ABRI dan PNS dengan menerapkan skrining (screening) yang ketat. 
Penelitian mengenai PKI telah banyak dilakukan oleh peneliti dari berbagai sudut pandang, beberapa diantaranya dilihat dari sudut pandang pandang politik, Soemarmi dkk. (2001), misalnya, berfokus pada proses pergantian presiden sebelumnya oleh Soekarno dengan presiden baru yakni Soeharto, langkah suksesi yang ditempuhnya dengan menyuarakan istilah 'bahaya laten PKI' dan pengaturan hukum yang mendukungnya; Fic (2004) menitikberatkan penelitiannya pada wacana konspirasi dalam menganalisis peristiwa kudeta 1 Oktober 1965; Studi Wieringa (2010) melihat bagaimana gerakan perempuan dihancurkan pasca kejatuhan PKI melalui pendekatan politik seksual; dan Herlambang (2013) yang berfokus pada bagaimana upaya sistematis pemerintah Orde Baru memanfaatkan produk-produk budaya untuk melegitimasi pembantaian 1965-1966. Artikel ini berfokus pada bagaimana negara mengkonstruksikan memori kolektif dengan penggunaan beragam strategi, teknik dan wacana-wacana pendisiplinan dengan tujuan untuk menormalisasikan wacana anti-komunis di Indonesia.

\section{Metode Penelitian}

Penelitian ini dilakukan di salah satu Markas Besar TNI di Jakarta dan Museum Lubang Buaya di jalan Raya Pondok Gede Jakarta. Informan yang berpartisipasi dalam penelitian ini berjumlah 5 orang, yakni anggota TNI OMSP (TNI Operasi Militer Selain Perang), yang berusia antara 38 dan 57 tahun, yang direkrut secara snowball sampling atas petunjuk informan pertama dan seterusnya.

Pengumpulan data dilakukan melalui wawancara mendalam, observasi, dan review dokumen. Wawancara dilakukan dengan menggunakan guide interview, dengan topik-topik wawancara menyangkut prosedur penerimaan anggota baru TNI, tujuan skrining, sejarah G30S/PKI, bahaya PKI, pemberontakan PKI di Indonesia, serta organisasi terlarang binaan PKI.

Observasi dilakukan di Museum Lubang Buaya dengan pertimbangan museum ini merupakan hasil konstruksi TNI mengenai peristiwa G30S/PKI, dengan mengamati patung, diorama, relief, pesan-pesan dan sisa-sisa peristiwa 65 yang masih tersimpan dalam museum tersebut. Berbagai dokumen, seperti buku saku TNI, buku sejarah TNI, majalah, koran online, yang pro ataupun kontra terhadap G30S, buku saku TNI dan buku sejarah dari tahun 1982-2012. Selain buku-buku teks dan Museum Lubang Buaya, observasi juga dilakukan pada beberapa foto dan film digunakan untuk mencari informasi mengenai penyampaian cerita PKI kepada publik, seperti Film G30S/PKI.

Analisis diawali dengan melakukan closereading terhadap fieldnotes dan transkrip wawancara yang terkumpul. Close-reading diikuti dengan coding dan sorting dengan mengidentifikasi, memilah, dan mengaktegorisasikan data-data yang didapatkan berdasarkan tematemanya, yakni mengenai prosedur penerimaan anggotaa baru TNI, tahap pendidikan dan doktrin bagi anggota TNI, perluasan cakupan skrining, dan upaya pembersihan PKI oleh TNI.

Wawancara didahului dengan penjelasan tentang maksud dan tujuan penelitian, menanyakan kesediaan calon informan (informed consent) untuk diwawancarai, menjelaskan bahwa semua informasi dijaga kerahasiaannya (confidential) dan nama-nama informan yang terlibat dalam penelitiaan ini juga disamarkan (pseudonym).

\section{Memori Kolektif: G30S/PKI \& TNI}

Olick (1999:337) menganalisa memori kolektif dengan memasukkan faktor representasi kolektif (simbol-simbol, makna, narasi, dan ritual yang tersedia bagi publik), struktur kebudayaan (sistem peraturan atau pola yang memproduksi representasi), konstruksi sosial (pola interaksi), dan memori-memori individual yang terbentuk secara kultural dan sosial. Olick (1999:336) juga mengemukakan tiga prinsip dalam menganalisa dan mengolah materi yang ditemukan di dalamnya. Pertama memori kolektif tidak bersifat monolitik. Pengingatan kolektif merupakan proses yang sangat kompleks, melibatkan banyak macam orang, praktik, materi, dan tema. Yang kedua, konsep memori kolektif akan mendorong kita untuk melihat memori sebagai residu otentik akan masa lalu atau sebaliknya sebagai konstruksi yang 
sifatnya dinamis dalam masa kini. Proses mengingat-ingat yang kompleks selalu merupakan proses negosiasi yang cair antara hasrat di masa kini dan peninggalan dari masa lalu. Ketiga, harus diingat bahwa memori adalah sebuah proses, dan bukan sebuah benda. Memori kolektif adalah sesuatu yang kita lakukan bukan sesuatu yang dimiliki. Oleh karenanya diperlukan perangkat analisis yang sensitif terhadap keberagaman, kontradiksi, dan dinamikanya.

Narasi PKI berikut merupakan narasi tentang bagaimana negara mengkonstruksi memori kolektif. Dalam upaya pemerintah Indonesia untuk menyatukan kekuatan angkatan bersenjata di bawah satu komando, diharapkan dapat mencapai efektifitas dan efisiensi dalam melaksanakan peran ABRI, serta tidak terpengaruh oleh kepentingan kelompok politik tertentu. Upaya tersebut menghadapi berbagai tantangan, terutama dari PKI yang pada tahun 1965 telah menguasai sepertiga dari kekuatan ABRI dengan melakukan penyusupan dan pembinaan khusus, serta memberi pengaruh terhadap Presiden dan Panglima Tertinggi ABRI untuk mengingkari dan mengkhianati sumpah prajurit dan Sapta Marga demi kepentingan politik PKI. PKI merupakan sekelompok orang yang berpaham komunis dan menentang kapitalis yang bersesuaian dengan lambang kebesarannya, yakni palu arit, yang berarti partai rakyat kecil, yang mengakomodir keinginan-keingnan rakyat kecil. PKI mengajak orang-orang kecil bergabung khususnya para petani dengan imingiming akan memberikan lahan pertanian. Pasca kemerdekaan, PKI gencar melakukan pemberontakan, diantaranya Peristiwa Tiga Daerah (pemberontakan yang terjadi di Kabupaten Pemalang, Tegal, dan Brebes), terror gerombolan Ce' Mamat, pemberontakan di Cirebon, revolusi sosial di Langkat, dan yang paling fenomenal adalah pemberontakan PKI di Madiun yang berujung pada berdirinya Sovyet Republik Indonesia (SRI).

Menurut Barka, PKI yang pada awalnya hanya melakukan gerakan bawah tanah yang secara intensif mulai menyebarluaskan pengaruhnya kepada rakyat Indonesia secara besarbesaran dan melakukan aksi massa terbuka melawan pemerintah. Itupun dianggap tidak cukup karena belum dapat menguasai TNI-AD seutuhnya yang dinilai PKI sangat anti-komunis dan memiliki militansi serta semangat nasional yang tinggi. Sejumlah anggota TNI yang proPKI selalu menentang konsepsi TNI-AD terkait pembinaan masyarakat karena dianggap menghambat program PKI dalam memonopoli pembinaan masyarakat. Sebagai lawan langsung dari PKI, TNI-AD merasa posisinya semakin terpuruk karena berbagai kebijakan politik yang dilakukan oleh Presiden Soekarno ternyata sangat menguntungkan PKI. PKI menyokong hampir semua kebijakan yang dikeluarkan Presiden Soekarno dalam rangka tahapan strategi yang menguntungkan PKI, sehingga banyak yang menduga bahwa Soekarno adalah pro-PKI. Informasi mengenai dugaan keterlibatan Soekarno dalam skenario PKI diungkapkan oleh Barka, sebagai berikut:

Tau nasakom kan? Nasakom itu yang mempermulus jalan PKI. Itu skenarionya Soekarno. Sebenarnya Komunis itu tidak cocok di Indonesia. Sekarang kan tinggal Cina yang masih kekeuh bertahan dengan partai komunisnya.... mereka (komunis) itu kan ateis sebenarnya' (Barka, 13 April 2014).

Dugaan keterlibatan Soekarno bukan tanpa alasan. Menurut Barka, melalui politik dan indoktrinasi Nasakom (Nasionalis, Agama, Komunis), Soekarno memberi kekuasan PKI untuk memperluas pengaruh. Nasakom menjadi salah satu kekuatan penting PKI pada masa Demokrasi Terpimpin bersama Presiden Soekarno dan Angkatan Darat.

Bahkan sebelum peristiwa G30S, PKI gencar menyebarluaskan desas-desus yang semakin memojokkan ABRI, diantaranya dengan melakukan fitnah terhadap Dewan Jendral-7 perwira tinggi $A D$ yang terdiri atas Jendral A. H. Nasution, Letnan Jendral A. Yani, Mayor Jendral S. Parman, Mayor Jendral Haryono MT, Brigadir Jendral Sutojo Siswamiharjo, dan Brigadir Jendral D. I. Pandjaitan—bahwa mereka adalah kelompok yang tidak loyal terhadap presiden dan mengutamakan kerjasama dengan imprealis. Isu ini menyebar ke masyarakat dan memberi kesan 
bahwa TNI-AD telah mengkhianati perjuangan rakyat Indonesia, sehingga menimbulkan kemarahan rakyat. Untuk lebih memojokkan ABRI, PKI melancarkan isu bahwa Dewan Jendral berencana melakukan kudeta atau merebut kekuasaan Soekarno. Sebelum disebarluaskannya isu ini, pimpinan PKI, D. N. Aidit menuduh bahwa TNI-AD merupakan sumber kekacauan ekonomi dan konsumen terbesar dari uang rakyat. Di dalam buku sejarah TNI Jilid III, selain isu Dewan Jendral, dokumen milik Sir Andrew Gilchrist-Duta Besar Inggris di Jakarta (1963-1966)—diisukan oleh PKI berisi dukungan terhadap neokolonialisme. Dokumen yang memakai nama Sir Andrew Gilchrist terdapat kata-kata our local army friends yang ditafsirkan serupa dengan Dewan Jendral. Hal ini dimanfaatkan PKI untuk menuduh bahwa Angkatan Darat mempunyai hubungan dengan neokolonialisme. Kedua isu ini merupakan bagian dari offensive revolution PKI untuk menghilangkan kepercayaan rakyat terhadap TNI-AD yang diciptakan secara sistematis oleh PKI (Sejarah TNI Jilid III 1960-1965, 2000:187). Rangkaian isu yang ditujukan untuk memojokkan ABRI tersebut dibenarkan oleh Barka yang menyatakan bahwa 'fitnah itu datang bertubitubi...macam-macamlah gosipnya.. yang paling saya ingat itu isu Dewan Jendral.. kalau katanya jendral-jendral itu penghianat' (Barka, 13 April 2014).

Untuk menghadapi aksi-aksi PKI tersebut, para pimpinan TNI-AD berusaha untuk mengatasinya dengan cara melakukan manuvermanuver di berbagai bidang, sebagaimana yang diungkapkan Barka bahwa upaya yang dilakukan diantaranya membentuk Bintara Desa (Babinsa) dan Komando Rayon Militer (Koramil) untuk menekan aksi-aksi PKI di tingkat desa dan kecamatan dan melakukan pembinaan generasi muda Islam yang tergabung dalam Himpunan Mahasiswa Islam (HMI). Di lingkungan TNI$\mathrm{AD}$, dibentuk Dewan Penelitian dan Pengembangan yang tugasnya mengidentifikasi dan mengantisipasi gerak-gerik PKI.

Puncak pemberontakan yang dilakukan PKI yang melakukan penculikan dan pembunuhan terhadap pejabat TNI-AD. Seluruh persiapan telah dilakukan di Lubang Buaya mulai dari penyiapan pasukan untuk menculik para pejabat, hingga titik lokasi untuk melakukan penyiksaan dan penguburan. Sasaran penculikan dan pembunuhan oleh PKI ditujukan pada Dewan Jendral atas pertimbangan bahwa sebagai pejabat TNI$\mathrm{AD}$, mereka telah menghambat langkah PKI dalam memperluas manuver mereka di segala bidang dan merebut kekuasaan negara dengan menentang berbagai tuntutan PKI, diantaranya Nasakom. Sikap TNI-AD yang nasionalis ini dianggap mengancam keberadaan PKI, seperti yang diungkapkan oleh Mica berikut ini:

Jendral ini kan pejabat...namanya juga pejabat, jadi mereka itu yang paling keras menentang usaha PKI dalam menguasai pemerintahan... ibaratnya mereka itu barisan terdepan yang sangat berseberangan dengan PKI... apalagi A. Yani yang pemikirannya, pandangannya bertolak belakang dengan pemimpin PKI, si Aidit itu (Mica, 19 April 2014).

Mica juga menceriterakan bahwa pada tanggal 30 September 1965, pasukan-pasukan seperti Pemuda Rakyat, Gerwani, dan Resimen Cakrabirawa dikumpulkan oleh anggota PKI di Lubang Buaya dan dipropaganda bahwa ke 7 Jendral yang akan diculik adalah tokoh-tokoh Dewan Jendral yang akan melakukan kup terhadap Presiden Soekarno. Penculikan dilakukan pada tanggal 1 Oktober 1965 pukul 02.30 pagi. Prajurit dibagi dalam 7 kelompok kemudian disebar untuk menjemput ketujuh Jendral dirumahnya masing-masing dengan alasan bahwa mereka diperintahkan oleh Presiden untuk menghadiri pertemuan. Semua sasaran berhasil dikirim ke Lubang Buaya dalam kondisi masih hidup, kecuali A. Yani yang tertembak di rumahnya.

Setibanya di Lubang Buaya, para korban penculikan diserahkan kepada pasukan yang telah menunggu untuk dibunuh dan dikuburkan. Kedatangan para Jendral TNI-AD disambut dengan teriakan dan caci maki. Mereka yang masih hidup mendapatkan penyiksaan di luar batas prikemanusiaan oleh gerombolan G30S/PKI, dan kemudian di bunuh. Mayat mereka kemudian dimasukkan kedalam sumur 
tua. Setelah tanggal 3 oktober 1965 G30S/PKI telah ditumpas oleh operasi ABRI dibawah pimpinan Mayor Jendral Suharto sekaligus melakukan pengangkatan ke 7 jenazah para jendral dari sumur yang disebut 'sumur maut' (Sejarah TNI Jilid III 1960-1965, 2000:206).

Kegagalan demi kegagalan skenario PKI tidak membuat pihak komunis berhenti dalam memantap-kan rencananya untuk menguasai pemerintahan di Indonesia. Tuntutan untuk memasukkan antek-antek PKI dalam kabinet juga mengalami kegagalan, meskipun ada diantaranya sudah diangkat sebagai pejabat pemerintah di pusat, di daerah, maupun di luar negeri sebagai duta besar. Aksi pemberontakan lainnya juga terjadi, seperti peristiwa Bandar Betsy, Kanigoro, dan Indramayu makin memanaskan situasi dalam negeri.

\section{Konstruksi Negara \& PKI}

Berbagai upaya yang dilakukan negara, khususnya TNI dalam membangun citra negatif tentang gerakan-gerakan PKI, sehingga citra yang nampak dalam memori masyarakat sipil terhadap PKI memberikan dampak traumatik yang mendalam bagi masyarakat Indonesia. Berikut berbagai upaya dilakukan negara untuk mengonstruksi pengetahuan masyarakat terhadap PKI.

\section{Monumen Pancasila Sakti: PKI Dalam Konstruksi TNI}

Monumen Pancasila Sakti didirikan tepat di lokasi terjadinya peristiwa G30S/PKI atas inisiatif Presiden ke-2 Indonesia, Suharto, pada Agustus 1973. Monumen yang berada di area seluas $\pm 14 \mathrm{Ha}$ ini berlokasi di Desa Lubang Buaya, Kecamatan Cipayung, Jakarta Timur (lihat Gambar 1).

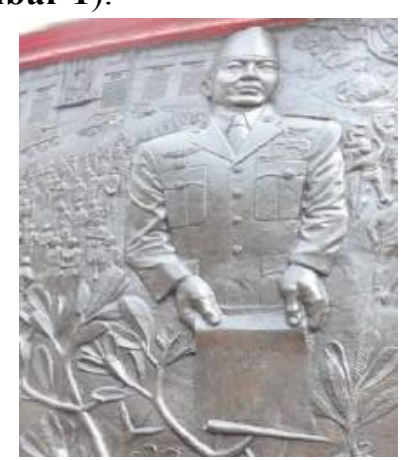

Gambar 1. Monumen Pancasila Sakti
Pada tahun 1980, Pusjarah TNI (Pusat Sejarah TNI) mendapatkan tugas sebagai pengelola dan penanggungjawab monumen melalui Surat Keputusan Presiden No. 51/1980 yang bertujuan untuk mengenang perjuangan para pahlawan revolusi dalam mempertahankan ideologi negara Indonesia, yakni Pancasila dari berbagai ancaman ideologi komunis yang pada era tahun 60-an memiliki suara yang cukup besar pada pemilu. Sebelum menjadi sebuah monumen dan museum, tempat ini merupakan tanah atau lahan kosong yang dijadikan sebagai markas komando dan pusat pelatihan kemiliteran PKI menjelang pemberontakan, serta menjadi tempat penyiksaan dan pembuangan mayat ke 7 Jendral TNI-AD. Dalam kaitan dengan ini Lukas mengungkapkan bahwa:

Jadi setelah turun surat keputusan, museum Lubang Buaya berada dibawah pantauan Pusjarah ABRI. Dulu namanya Pusjarah ABRI tapi dirubah menjadi Pusjarah TNI... daerah Lubang Buaya itu sebenarnya tanah kosong milik masyarakat yang dijadikan sebagai markas komando PKI. Untuk mengumpulkan massa, rapat, latihan militer, dan membuang jenazah 7 jendral. Pokoknya semua persiapan pemberontakan dilakukan di sana (Lukas, 8 April 2014).

Gedung Museum terdiri dari dua lantai yang berisi sisa-sisa peninggalan peristiwa G30S/PKI, diantaranya seragam dan pakaian ketujuh Jendral, senapan, dokumentasi berupa foto, dan diorama yang menggambarkan kronologis gerakan-gerakan PKI. Setiap diorama yang menggambarkan peristiwa tertentu dileng-kapi dengan deskripsi dalam dua bahasa, yakni Bahasa Indonesia dan Bahasa Inggris. Dioramadiorama yang tampilkan tidak banyak menceritakan puncak pemberontakan di tahun 1965, melainkan diorama yang menunjukkan bibitbibit pergerakan PKI dari tahun 1945.

Di luar museum terdapat serambi penyiksaan yang didalamnya berisi ragam diorama penuh darah yang detil dan mampu berkisah dengan backsound yang membuat diorama-diorama tersebut terasa 'hidup'. Di dalam serambi terdapat 17 diorama yang terdiri dari 12 diorama PKI yang menggunakan seragam berwarna hijau 
lengkap dengan senjata, diantaranya ada 2 prajurit perempuan, 1 orang perempuan yang merupakan pendukung PKI, dan 4 jendral. Sebanyak 12 prajurit PKI terlihat sedang melakukan kekerasan kepada ke 4 jendral dengan memukul bagian kepala dengan ujung senjata, menikam dengan celurit, dan beberapa juga terlihat sedang berjaga di bagian luar serambi. Seorang wanita yang merupakan simpatisan PKI menggunakan baju berlengan panjang dan sarung sedang memegang besi terlihat sangat marah. Sedangkan ke 4 jendral terlihat berlumuran darah karena luka sobek di beberapa bagian tubuh mereka. Di serambi itu suasana penyiksaan dibangun untuk memperkuat upaya doktrin (lihat Gambar 2).

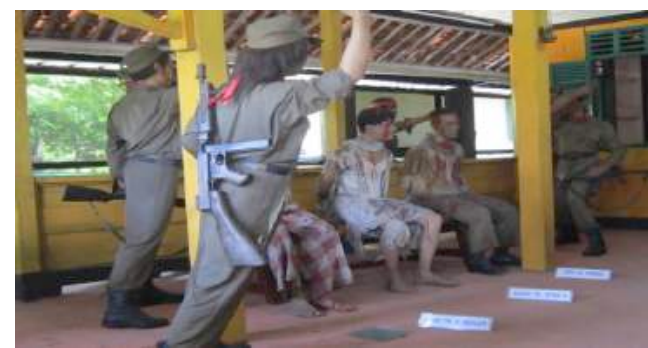

Gambar 2. Diorama Penyiksaan 4 Jendral TNIAD

Di sebelah kiri serambi penyiksaan terdapat bangunan megah menyerupai pendopo dengan ukiran Jawa yang terbuat dari kayu. Bangunan tersebut adalah lokasi 'sumur maut', yang berdiamter $75 \mathrm{~cm}$ dengan kedalaman $12 \mathrm{~m}$, dimana ke 7 jendral dikuburkan setelah sebelumnya dibunuh di serambi penyiksaan. Di bagian permukaan terdapat bercak merah menyerupai darah sebagai penghias yang menambah kesan mistis dari 'sumur maut' tersebut (lihat Gambar 3).

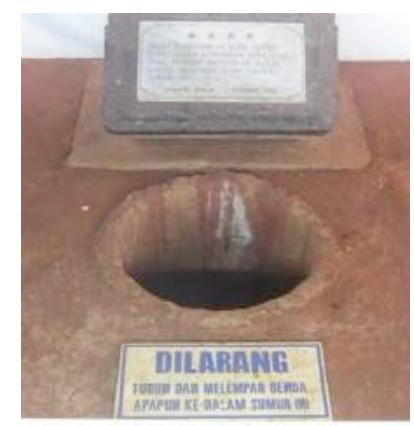

Gambar 3. 'Sumur Maut'
Bergeser ke sebelah utara 'sumur maut' terdapat tugu dan relief Monumen Pancasila Sakti. Di monumen itu terdapat patung ke 7 jendral TNI yang berdiri membentuk formasi setengah lingkaran dengan latar belakang patung garuda Pancasila. Kesan kokoh dan gagah sangat kentara. Dinding bagian bawah tugu dihiasi ukiran yang menceritakan kekacauan, pemberontakan, dan pertumpahan darah akibat ulah PKI dan penumpasannya oleh ABRI dan rakyat Indonesia (lihat Gambar 4).

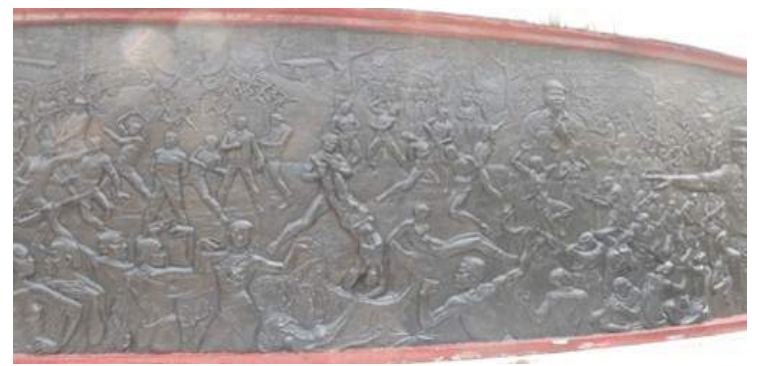

Gambar 4. Relief Peristiwa Prolog G30S/PKI

Masih di lokasi yang sama, terdapat rumah yang dijadikan sebagai pos komando oleh gerombolan PKI untuk mempersiapkan penculikan terhadap ke 7 jendral TNI-AD dan rumah dapur umum yang dijadikan sebagai tempat penyediaan sarana konsumsi gerombolan G30S/PKI. Di dalam rumah pos komando masih terdapat beberapa peninggalan, diantaranya lampu, mesin jahit dan lemari kaca, sedangkan di dapur umum terdapat meja, kursi, lemari, tempat tidur, wajan, dandang, dan genteng rumah. Di beberapa sudut museum juga terdapat truk dodge, mobil dinas Letjen A. Yani, mobil dinas Suharto, dan panser Saracen (mobil yang digunakan untuk berpatroli melindungi keamanan ibukota, mobil 6 roda tersebut juga menjadi ikon dalam film 'Pengkhianatan G30S/ PKI').

\section{Penuntasan Pasca G30S/PKI}

Tanggal 1 oktober 1965 merupakan hari bersejarah kelam Indonesia yang menunjukkan persaingan antara kekuatan komunis dan kekuatan anti-komunis se dunia yang berkepanjangan dan ruwet, yang meluas dari perseteruan di tingkat desa sampai ke politik tingkat tinggi (Roosa 2008:252). Untaian peristiwa yang mengenaskan tidak hanya terhenti pada pem- 
bunuhan ke 7 Jendral TNI-AD sebagai usaha untuk melakukan kudeta (pengambilan kekuasaan) yang kemudian dituduhkan kepada anggota PKI.

Setelah pengambilalihan sementara pimpinan TNI-AD untuk mengisi kevakuman kepemimpinan, Suharto melalui Kolonel Sarwo Edhi, yang ketika itu menjabat sebagai Komandan Resimen Para Komando Angkatan Darat (Komando RPKAD) melakukan penyerangan ke gedung Telekomunikasi dan RRI yang telah dikuasai oleh pasukan G30S/PKI untuk melakukan terror. Setelah kedua sarana komunikasi tersebut telah berhasil direbut kembali, disebarkanlah pidato Kolonel Sarwo Edhi yang meng-informasikan bahwa Pimpinan Angkatan Darat untuk sementara dikendalikan oleh Suharto. Pengaruh Suharto semakin kuat setelah ia menerima Surat Perintah 11 Maret 1966 dari Soekarno yang berisi mengenai pemindahan kekuasaan kepada Suharto. Berawal dari surat perintah inilah Suharto melakukan penangkapan terhadap menteri dan pembantu Soekarno dengan alasan 'diamankan'.

Suharto bersama para pendukungnya mulai melakukan upaya-upaya pembersihan dengan melakukan pembantaian bagi siapa saja yang terdeteksi sebagai pengikut PKI dan Soekarno, mulai dari partai-partai nasional dan Islam, organisasi buruh, petani, Gerwani, Pemuda Rakyat, guru, dan pamong desa. Salah satu etnis yang tak luput terseret dalam pergolakan ini adalah etnis Tionghoa, dimana etnis tersebut mendapatkan perlakuan diskriminatif dari negara, karena menurut Suharto etnis Tionghoa di Indonesia disinyalir memiliki hubungan erat dengan PKI pada waktu itu. Akibatnya, kelompok-kelompok tersebut harus 'menelan pil pahit' atas kebijakan Suharto yang ingin membumihanguskan PKI dari tanah air sebagai balasan bagi mereka yang telah melakukan pembantaian secara kejam dan sadis terhadap ke 7 Jendral TNI-AD (Bastian, 2013:7).

Upaya pembersihan PKI melibatkan tentara dan rakyat sipil yang sebelumnya mendapatkan pelatihan khusus dari Sarwo Edhie Wibowo. Setelah mengikuti pelatihan, para rakyat sipil ini berhasil menangkap ratusan ribu orang berdasar- kan daftar orang PKI yang diberikan kepada Komandan RPKAD yang diduga terkait akan disortir terlebih dahulu: siapa saja yang aktivis dan siapa saja yang termasuk anggota pasif. Dalam buku yang ditulis oleh Zulkifli \& Dhyatmika (2012) yang berjudul Sarwo Edhie dan Misteri 1965, Harold Crouch menjelaskan bahwa aktivis PKI umumnya dieksekusi, sedangkan anggota pasif dipenjarakan tanpa diadili.

Buntut upaya pembersihan ini adalah banyaknya korban yang tewas, dan yang terbanyak ada di Jawa Tengah, Jawa Timur, Bali, Sumatra Utara, dan Aceh. Jumlah korban keseluruhan memang masih simpang siur, namun beberapa sumber media cetak menyatakan bahwa korban mencapai jutaan orang. Keseriusan Suharto dalam membumi-hanguskan PKI dan antek-anteknya diungkapkan dalam buku yang ditulis oleh Robert E. Elson (2008:14), Suharto: A Political Bioghraphy, bahwa:

Setelah menyaksikan dengan mata kepala saya sendiri apa yang kita temukan di Lubang Buaya, tugas utama saya adalah menghancurkan PKI, menghancurkan perlawanan dimana pun, di ibu kota, di daerah, dan juga di persembunyian di gunung-gunung.

Tekad serupa juga dimiliki Sarwo EdhieKomandan Resimen para komando Angkatan Darat-yang menggerakkan pasukan khusus Angkatan Darat untuk berkeliling Jawa dan Bali, serta melatih pemuda Nahdlatul Ulama (NU) menjadi 'ujung tombak' operasi besar melumpuhkan basis-basis PKI. Dorongan Sarwo Edhie dalam melakukan penumpasan lebih dikarenakan hubungan baik seperti kakakberadik yang terjalin antara dirinya dan A. Yani. Istri Sarwo Edhie mengungkapkan bahwa sesaat setelah mendapatkan kabar tentang kematian A. Yani, Sarwo menangis dihadapan fotonya. Setiap hari Sarwo meletakkan setangkai bunga di samping foto sahabatnya. Dalam buku yang tulis oleh John Hughes berjudul The End of Soekarno sebagaimana dikutip oleh Zulkifli \& Dhyatmika(2012:14), Sarwo Edhie mengungkap kan, bahwa: 
Ketika saya mendesak Jenderal Suharto agar segera ditugaskan ke Jawa Tengah, saya sama sekali tidak ingin mencari jasa atau kemegahan bagi diri saya sendiri. Saya hanya ingin mengajak rakyat menumpas PKI sampai ke akar-akarnya. Saya ingin membuka kedok PKI, kemudian menunjukkan ke rakyat, siapa sebenarnya yang berada di belakang Gestapu.

Dorongan inilah yang dimanfaatkan oleh Suharto untuk menumpas G30S/PKI yang dituduh didalangi oleh PKI. Apalagi Sarwo Edhie menggenggam pasukan elit Angkatan Darat yang memiliki ambisi untuk membumi hanguskan anggota PKI.

Upaya-upaya lainnya yang dilakukan oleh rezim Suharto adalah pembuatan dan pemutaran film G30S/PKI yang ditayangkan di televisi selama masa pemerintahan Orde Baru $( \pm 32$ tahun) pada setiap tanggal 30 September. Selain itu, hampir semua buku sejarah yang digunakan sebagai bahan ajar di tingkat SD, SMP, dan SMA menyajikan uraian mengenai peristiwa G30S/PKI dengan versi yang serupa. Bahkan hingga kini, selain sebagai objek wisata, sejumlah SD di Jawa, menjadikan kunjungan ke Museum Pancasila Sakti sebagai bagian dari proses belajar-mengajar pada Mata Pelajaran Sejarah, sehingga siswa-siswi SD wajib mengunjungi museum tersebut (lihat Gambar 5).

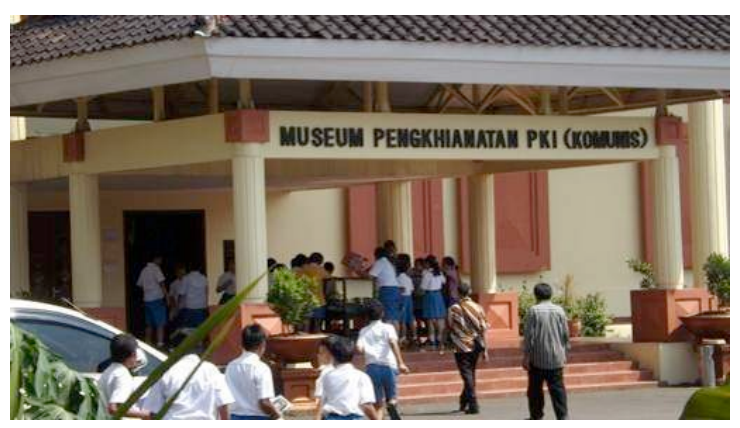

Gambar 5. Kunjungan Siswa-Siswi SD di Museum Pancasila Sakti

Upaya untuk menghilangkan jejak-jejak soekarnoisme di berbagai tempat di Jakarta juga gencar dilakukan oleh rezim Orde Baru. Misalnya bangunan-bangunan bersejarah yang sebenarnya memiliki nilai sejarah yang tinggi justru direnovasi dan diganti namanya oleh
Suharto, diantaranya salah satu wisma yang menjadi rumah kediaman Soekarno bersama isteri ke 5 beliau, yakni Ibu Ratna Sari Dewi sekaligus menjadi tempat terakhir disemayamkannya Soekarno. Hal ini diungkapkan oleh Lukas, bahwa:

Nah...kalau museum ini ada sejarahnya dulu... ada kaitannya dengan PKI juga. kenal dengan ibu Dewi? Ratna Sari Dewi itu istri ke 5 Soekarno. Jadi museum ini dulunya rumah ibu Dewi, tapi dijadikan museum sekarang konon kabarnya untuk menghilang-kan jejak-jejak soekarnoisme oleh Suharto (Lukas, 8 April 2014).

Herlambang, dalam bukunya 'Kekerasan Budaya Pasca 1965', mengungkapkan bahwa ideologi anti-komunis ini merupakan bentukan Orde Baru yang dapat bertahan lama karena adanya kampanye kebudayaan yang melegitimasi kekerasan terhadap simpatisan komunis pada 1965-1966. Kampanye kebudayaan yang dimaksud Herlambang adalah kemunculan narasi sejarah pemerintah Orde Baru, yang dituangkan melalui karya-karya sastra dan film oleh para penulis anti-komunis dan militer (Herlambang 2013:3).

Hari berganti hari, bulan berganti bulan, tahun berganti tahun, berbagai upaya pembasmian PKI yang dilakukan oleh militer atas komando Jendral Suharto terus berlanjut. Jutaan korban dan ratusan ribu orang yang tertuduh sebagai simpatisan PKI berhasil 'diamankan'. Orang-orang yang telah dipenjarakan mengalami masa-masa sulit karena menjalani hukuman tanpa proses pengadilan. Mereka yang diduga simpatisan pasif PKI juga mendapatkan berbagai tekanan dan diskriminasi dengan diberlakukannya kartu tanda penduduk (KTP) yang bertanda mantan tahanan politik (eks-Tapol). Label eksTapol yang diberikan tidak hanya berdampak secara individual, tetapi juga berefek pada seluruh keturunan yang bersangkutan. Istilah 'keturunan Tapol' menjadi bentuk diskriminasi yang paling ekstrim bagi mereka yang orangtua/ leluhurnya termasuk dalam kategori Tapol. Keturunan eks-Tapol mendapatkan perlakuan yang sangat diskriminatif, bahkan sangat mendera kelangsungan hidup mereka, seperti sulit mendapatkan pekerjaan, khususnya melarang 
orang-orang yang 'tidak bersih' menjadi PNS, TNI/Polri, guru atau profesi yang dianggap bisa memengaruhi masyarakat. Aturan 'bersih diri' dan 'bersih lingkungan' dikeluarkan oleh Departemen Dalam Negeri digunakan untuk membatasi ruang gerak para eks-Tapol atau orang-orang yang terlibat dalam G30S/PKI, terutama yang terkait dengan pekerjaan.

Selain istilah 'eks-Tapol', rezim Orde Baru juga memomulerkan frasa 'bahaya laten PKI'. Istilah 'bahaya laten PKI' mengandung arti ancaman yang berbahaya karena mampu mengobrak-abrik kestabilan NKRI, bahkan merusak dasar dan ideologi negara, yaitu Pancasila. (lihat Gambar 6).

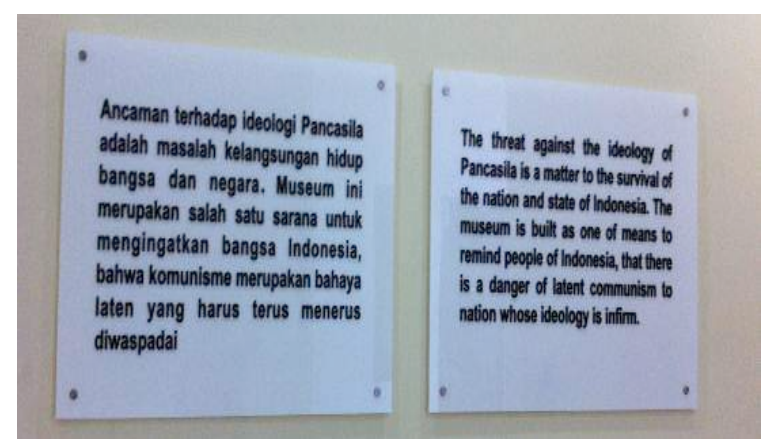

Gambar 6. Pesan Bahaya Laten Komunis

Pembersihan yang dilakukan hingga menelan jutaan korban, 'wajib tonton' film 'Pengkhiana$\tan$ G30S/PKI', pemuatan peristiwa G30S/PKI di dalam kurikulum pendidikan, penguburan jejak Soekarno yang diduga pro-PKI, perlakuan diskriminatif bagi para 'eks-Tapol', penerapan surat 'bersih diri' dan 'bersih lingkungan' bagi aparat pemerintah adalah berbagai upaya yang dilakukan oleh rezim Suharto untuk menumbuhkan dan menciptakan sudut pandang bahwa komunisme merupakan 'musuh negara'.

Namun, tumbangnya pemerintahan Suharto pada tahun 1998 tidak serta merta diikuti dengan memudarnya semangat anti-komunis yang puluhan tahun ditanamkan selama masa kepemimpinannya. Walaupun dalam pemerintahan Gusdur telah dicabut puluhan peraturan perundang-undangan berkaitan dengan eksistensi eks-Tapol, namun perlakuan diskriminatif tetap berlangsung.

\section{Rekrutmen TNI-AD: Bersih-Bersih dari PKI}

Untuk menjadi anggota TNI-AD, ada tiga tahapan tes yang harus dilalui: (1) Tes Penyediaan Berkas: tes ini ditangani oleh Sub-Panda (sub-panitia daerah), yakni bukti pendaftaran online, ijazah SD, SMP, SMA, Surat Keterangan Hasil Ujian Nasional (SKHUN), KTP, dan KTP orang tua beserta wali (jika ada), KK (kartu keluarga orang tua beserta wali), akta kelahiran, dan surat keterangan 'bersih diri' dan 'bersih lingkungan' dan berkelakuan baik; setelah lolos berkas, maka yang bersangkutan akan mengikuti (2) Tes Kesehatan: tes ini meliputi pemeriksaan kesehatan, pengujian jasmani, tes ideologi mental, dan pemeriksaan psikologi yang ditangani oleh panitia daerah (Panda); jika tahap kedua ini lolos, maka tes berikutnya (3) Tes Pengetahuan Umum, yang ditangani langsung oleh Panpus (panitia pusat). Aturan dan tata cara penerimaan, tahap-tahap tes yang diberlakukan, dan jumlah anggota yang diterima ditentukan oleh Menteri Hankam dan Kepala Staff TNI yang merumuskan pedoman penerimaan anggota TNI-AD.

Jika menilik Tes Penyediaan Berkas, maka surat keterangan 'bersih diri' dan 'bersih lingkungan' merupakan tahap awal yang dilakukan untuk menyingkirkan pengaruh-pengaruh PKI dalam tubuh TNI. Sedangkan bagian dari tes kedua, yakni tes ideologi mental, yang di zaman Suharto dikenal dengan istilah screening atau tes penelitian khusus (Tes Litsus), bertujuan untuk mengetahui latar belakang calon pendaftar dan keluarganya, organisasi formal dan informal yang diikuti, serta orientasi politiknya. Jika calon anggota TNI atau salah satu keluarganya pernah menjadi simpatisan aktif atau pasif dari PKI, maka secara otomatis ia akan digugurkan. ${ }^{1}$ Dalam kaitan dengan ini Lukas mengungkapkan:

\footnotetext{
${ }^{1}$ Jika merujuk kepada Lampiran Peraturan Panglima TNI, PKI termasuk kedalam ancaman non-militer berupa aksi radikal, yakni mengatasnamakan rakyat untuk kepentingan kelompok, golongan dengan cara yang ekstrim dan merongrong stabilitas nasional, kewibawaan pemerintah dan ideologi negara (Lampiran Peraturan Panglima TNI, 2010:27).
} 
Sebenarnya tes mental ideologi itu baru ada setelah peristiwa G30S/PKI, sebelumnya belum ada, tapi dulu namanya screening. Bukan TNI saja yang ada tes seperti itu, semua institusi pemerintah juga ada tesnya...tes ini penting diberlakukan...karena kalau tidak, kita bisa kecolongan PKI (Lukas, 8 April 2014).

Di zaman Orde Baru, setiap orang yang akan mendaftarkan diri ke instansi pemerintah akan berurusan dengan intel tingkat desa dan kecamatan untuk mendapatkan surat keterangan 'bersih diri' dan 'bersih lingkungan' karena pihak intel memang memiliki 'daftar hitam' sejumlah orang yang dianggap terlibat dengan G30S/PKI. Saat ini, pengurusan surat keterangan 'bersih diri' dan 'berkelakuan baik' telah dapat dilakukan di Kepolisian. Setelah tumbangnya Suharto dan semakin banyaknya ancaman yang dihadapi Indonesia, baik ancaman militer maupun non-militer, mendorong TNI untuk memperluas fungsi dan cakupan screening atau Litsus. Setelah dilakukan revisi, maka screening diganti menjadi 'tes ideologi mental' yang bertujuan serupa dengan screening. Tes semacam ini semakin ketat diberlakukan mengingat saat ini ancaman tidak hanya datang dari PKI, melainkan juga datang dari gerakan separatis serta terorisme yang juga semakin marak. Dalam kaitan dengan 'tes ideologi mental' ini, Barka mengungkapkan:

Intinya...tes Litsus itu sangat penting... itu tes terpenting setelah tes kesehatan... latar belakang calon dan keluarganya harus kita telusuri... orang-orang yang diterima sebagai TNI itu berarti mereka bersih dari organisasi terlarang, gerakangerakan bawah tanah yang mengancam NKRI, sekarang kan banyak itu gerakangerakan seperti itu, makanya kita harus tetap waspada, kalau jaman dulu, jamannya Suharto kan yang ditakutkan itu cuma PKI dan orgaisasi-organisasi binaannya (Barka, 13 April 2014)

Penerapan screening tidak hanya diberlakukan pada saat penerimaan anggota baru, tetapi juga pada saat anggota TNI akan menikah. Screening (Tes Litsus) yang serupa juga dijalani calon istrinya, yakni dengan menyerahkan surat 'bersih diri' dan 'bersih lingkungan' dan mengikuti tes wawancara terkait ideologi mental untuk mengetahui latar belakang dan asal-usul calon istri agar terjamin 'kebersihannya' untuk menghindari unsur-unsur yang sifatnya membahayakan, mengancam, apalagi memengaruhi kinerja suaminya nantinya. Pada sejumlah kasus, jika calon istri atau salah seorang anggota keluarganya terdeteksi sebagai pengikut dari organisasi terlarang, maka secara otomatis pasangan ini tidak mendapat izin untuk menikah, sebagaimana diungkapkan Barka, berikut ini:

Kalau mau jadi istri anggota TNI tidak gampang, banyak persyaratan yang harus dipenuhi. Misalnya adek mau nikah dengan tentara, adek harus mengurus surat 'bersih diri' dan 'bersih lingkungan', surat berbadan sehat, berkelakuan baik... surat bersih diri dan lingkungan ini juga harus ada untuk ayah dan ibu, jadi ayah ibu juga harus ada, bukan cuma anaknya yang mau nikah... pokoknya banyak itu yang diurus cuma saya agak lupa juga.. screening juga ikut.. kalau terdeteksi si calon istri ada hubungannya dengan PKI, tidak boleh nikah.. dibatalkan... ada itu anggota saya yang batal nikah karena ternyata tante pacarnya, kalau gak salah kakak pertama ibunya itu anggota Gerwani dulu...batal dia nikah...mau gimana lagi.. harus dibatalkan.. patah hati dia itu. Pokoknya masuk TNI harus 'bersih'... jadi orangorang yang terkait juga harus 'bersih'... tapi kasihan juga sih (Barka, 8 April 2014).

Peristiwa berdarah puluhan tahun silam rupanya telah menjadi kenangan yang sangat membekas dalam sejarah TNI. Upaya PKI yang dianggap untuk mengucilkan, merusak, dan mengadu domba TNI dengan Presiden dan rakyat Indonesia dinilai sebagai percobaan pembunuhan karakter dan pencemaran nama baik yang keji. Tidak hanya itu, pengkhianatan sejumlah anggota TNI yng termakan hasutan PKI menjadi peristiwa yang dianggap memukul dan menjatuhkan harga diri TNI. 
Dalam bidang politik, ekonomi, dan sosial budaya, naiknya Suharto sebagai Presiden Indonesia menjadi titik balik perubahan dimana dulunya Indonesia yang cenderung non-blok menjadi pro-barat dan pengikut Amerika Serikat. Ekonomi Indonesia yang dulunya berdikari berubah menjadi ekonomi yang tergantung pada modal asing. Kebebasan berpolemik juga dibatasi, seolah-olah satu, tidak ada perbedaan dan seragam.

\section{Doktrin-Doktrin dalam Proses Pendidikan TNI}

Setelah melewati berbagai ancaman perpecahan, TNI terus berupaya untuk melakukan introspeksi dan berbenah diri dalam meningkatkan kualitas personelnya dengan mendirikan berbagai macam lembaga pendidikan. Upaya itu dilakukan untuk menyeragamkan kemampuan, pengetahuan, dan wawasan, khususnya bagi para perwira TNI-AD yang memiliki latar belakang berbeda-beda, upaya penyatuan ideologi. Semua prajurit berasal dari kalangan masyarakat biasa yang dicekoki oleh berbagai paham politik yang hidup dan berkembang di daerah masingmasing. Keragaman daerah asal dan paham politik inilah yang ingin dihapuskan oleh pemerintah untuk membentuk sosok prajurit yang memiliki jati diri pejuang, penegak, dan pembela politik serta ideologi negara. Barka mengungkapkan bahwa:

Perlu... pendidikan itu perlu sekali, jadi setelah diterima, anggota baru langsung diasramakan untuk mengikuti pendidikan. Nah... disini kita akan melakukan doktrin... menyalurkan, menanamkan, menyuntikkan semangat prajurit biar mereka cinta negara, tangguh, tidak tergoyahkan...karena mereka ini kan latar belakangnya beragam, kita tidak pernah tau sebelumnya apa saja yang pernah dilakukan diluar sana...meskipun sudah melalui litsus, kita harus tetap waspada... (Barka, 13 April 2014).

Pentingnya mengikuti pendidikan juga diungkapkan oleh Mica bahwa:

Masa pendidikan itu masa yang paling krusial karena disitulah pembentukan fondasi ke-tentaraan. Masa-masa itu yang akan menentukan kualitas tentara untuk penyatuan pemikiran, ideologi dan lainlain. Jadi harus seragam dan satu (Mica, 19 April 2014).

Proses dan orientasi pendidikan dan pembentukan perwira di masa perang kemerdekaan yang dilakukan dalam situasi serba darurat dan terdesak untuk memenuhi kebutuhan tenaga perwira muda dalam menghadapi ancaman dan pertempuran dengan penjajahan di Indonesia. Pendidikan dilakukan di tengah-tengah kesibukan menegakkan kedaulatan negara. Lembaga pendidikan pada saat itu bukan atas perintah pimpinan, tetapi atas inisiatif komandan pasukan setempat (Moehkardi 1981:27).

Pada tanggal 5 Oktober 1951, Sapta Marga diresmikan sebagai pedoman hidup dan pengamalan Pancasila dalam kehidupan prajurit TNI. Pimpinan TNI-AD membentuk Lembaga Candradimuka untuk penanaman dan penghayatan Sapta Marga dalam jiwa prajurit. Untuk itu setiap perwira secara bergantian mengikuti pendidikan ini. Keutamaan Sapta Marga dalam kehidupan prajurit juga dibenarkan oleh Lukas bahwa 'kalau itu sumpah TNI... Sapta Marga itu kan intinya adalah keharusan berpegang teguh pada Pancasila, hanya Pancasila. Komuniskomunis itu tidak ada... itu angan-angan yang mustahil' (Lukas, 8 April 2014) (lihat Gambar 7).

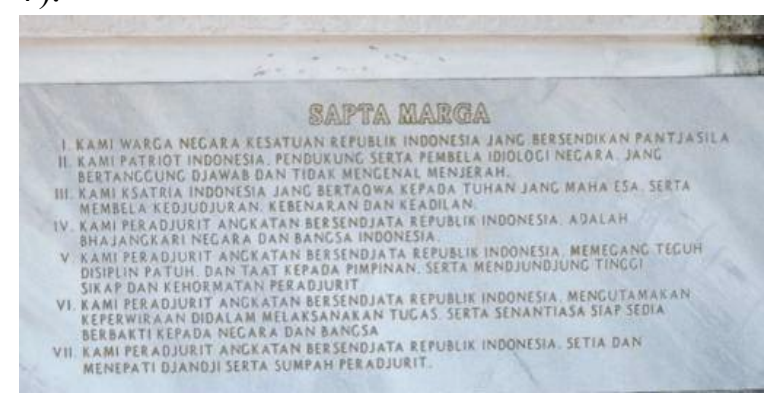

Gambar 7. Sapta Marga TNI di Museum Pancasila Sakti

Selain Lembaga Candradimuka, juga didirikan SSKAD (Sekolah Staf dan Komando Angkatan Darat) untuk pengembangan doktrin. Dewan Penelitian dan Pengembangan Doktrin AD berhasil merumuskan konsep Doktrin Perang Wilayah/Perang Rakyat Semesta (sekarang Doktrin Pertahanan Negara). Doktrin Pertahanan Negara merupakan doktrin perang kemerdekaan yang disesuaikan dengan kondisi 
dan situasi baru pada saat itu. Konsep ini diterima oleh pemerintah yang kemudian dikukuhkan menjadi Ketetapan MPRS. Inti dari Perang Wilayah adalah bentuk perang ideologi yang dilakukan untuk mempertahankan ideologi negara Pancasila dan doktrin revolusi lainnya. Doktrin ini dirumuskan untuk membendung manuver kaum komunis di Indonesia.

Dengan diresmikannya Doktrin Perang Wilayah ternyata menimbulkan kemarahan pihak PKI yang menganggap bahwa doktrin ini merupakan halangan terhadap strategi PKI karena mencakup unsur territorial, yakni menyangkut penguasaan wilayah oleh TNI-AD. PKI mencoba menyudutkan TNI-AD dengan Doktrin Perang Wilayah dan menawarkan agar menggantinya dengan Doktrin Perang Revolusi Indonesia dengan alasan bahwa doktrin tersebut lebih revolusioner. Sebagian prajurit TNI-AD menganggap bahwa tawaran PKI tersebut sebagai 'tanda bahaya' (Sejarah TNI Jilid III 1960-1965, 2000:70).

Selain Doktrin Perang Wilayah, ada pula Doktrin Tri Ubaya Cakti. Di dalam Doktrin Tri Ubaya Cakti terdapat tiga doktrin dasar, yaitu Doktrin Pertahanan Darat Nasional (Hanratnas), Doktrin Kekaryaan, dan Doktrin Pembinaan. Doktrin Tri Ubaya Cakti merupakan tiga ikrar dan tekad TNI-AD untuk selalu siap setia memikul tugas nasional serta mewujudkan citacita bangsa sesuai dengan tujuan nasional Bangsa Indonesia. Doktrin ini dicetuskan pada suatu masa yang penuh dengan slogan-slogan revolusioner, sehingga perumusannya mengikuti suasana politik saat itu agar dapat diterima diterima oleh Presiden. Misalnya, istilah Nasakom yang menjadi obsesi Soekarno hanya dimuat sekali didalam Tri Ubaya Cakti karena menuai protes dari kalangan pejabat TNI. Namun dalam lingkungan TNI-AD, Nasakom diganti dengan istilah Nasasos (Nasional, Agama, Sosialis). Lahirnya Doktrin Tri Ubaya Cakti juga merupakan upaya untuk merapatkan barisan TNI-AD dalam menghadapi berbagai kegiatan manuver yang dilakukan PKI (Moehkardi 1981; 27). Dalam kaitan dengan dicantumkannya istilah Nasakom di dalam
Doktrin Tri Ubaya Cakti ini dikomentari oleh Lukas, bahwa:

Karena waktu itu kepemimpinan Soekarno yah... jadi beberapa istilah seperti Nasakom termuat dalam Tri Ubaya Cakti. Tapi bagi kami, TNI-AD, ada pengertian lain... kalau Soekarno kan kata -kom nya yang dibelakang itu artinya komunis, kalau kita -komnya di ganti sosialis... jadi Nasasos (Lukas, 8 April 2014).

Doktrin-doktrin tersebut diatas digunakan sebagai pedoman TNI dalam rangka melaksanakan peran, fungsi, dan tugas pokok mereka sebagai alat pertahanan negara. Doktrin ini bertujuan agar TNI memiliki pedoman yang jelas dan tegas dalam melaksanakan tugas mereka agar terwujud kesamaan pola fikir, pola sikap, dan pola tindakan dalam pembinaan dan penggunaan kekuatan. Kedudukan doktrin TNI merupakan pedoman yang berada pada tataran strategis dan menjadi acuan dalam melakukan tugas pokok sdalam mempertahankan kedaultan negara.

\section{Normalisasi Anti-Komunis}

Pasca kemunculan G30S/PKI pada awal tahun 1966 yang juga ditandai oleh pengalihan jabatan dari Soekarno ke Suharto menjadi saatsaat kelabu bagi rakyat Indonesia, khususnya bagi orang-orang yang dituduh memiliki hubungan dengan PKI. Rakyat Indonesia dan militer bersama-sama dibawah kendali Suharto melakukan berbagai upaya pemusnahan PKI. Dari berbagai upaya yang dilakukan, ditemukan keseragaman, yakni memosisikan PKI sebagai 'kambing hitam' dari kekacauan politik di Indonesia yang berujung pada kematian ke 7 pejabat TNI-AD di Lubang Buaya.

Dari semua upaya tersebut, tidak terlihat satupun yang mencoba mengungkit peristiwa berdarah, yakni pembantaian massal pasca G30S/PKI oleh militer, dan seolah-olah dihapuskan. Ini menunjukkan bahwa upaya tersebut diatas bukanlah bagian untuk mengekspos peran militer dalam pembantaian massal, melainkan untuk mendobrak wacana anti-komunis, sehingga kekerasan dan diskriminasi terhadap 
simpatisan PKI dan mereka yang dituduh komunis bisa diterima publik sebagai hal yang normal dan alamiah (Herlambang 2013:130).

Kekuasaan merupakan sesuatu yang produktif dan bekerja dengan apa yang disebutnya sebagai normalisasi (Foucault 1984:4). Kekuasaan yang bersifat produktif adalah memoduksi sesuatu, seperti pengetahuan, realitas, dan juga klaim kebenaran. Dalam sebuah masyarakat, menurut Foucault, tatanan ditegakkan melalui apparatus berupa strategi, teknik, dan wacana-wacana pendisiplinan, sehingga masyarakat dalam suatu negara tidak lagi merasa sedang berada dalam jejaring kekuasaan. Pendisiplinan berupa wacana-wacana memang diselenggarakan negara terhadap rakyat dalam setiap rezim untuk mengendalikan warganya (Foucault 1979:13). Dalam konteks screening yang diberlakukan oleh TNI pada penerimaan anggota baru merupakan upaya pendisiplinan yang menjadikan dan melegitimasi wacana antikomunis yang 'dinormalisasikan'. Sampai pada saat wacana anti-komunis telah terbentuk dengan kokoh dan kuat kemudian digunakan untuk menghilangkan sisi kritis publik agar mudah di kelola dan dikendalikan karena adanya keseragaman pemahaman, sehingga rakyat yang sebenarnya sedang dikuasai oleh wacanawacana pendisiplinan merasa seolah 'tidak dikuasai'. Dengan kata lain, pendisiplinan yang melegitimasi wacana anti-komunis oleh negara melalui TNI merupakan upaya untuk menghilangkan 'kesadaran masyarakat'.

\section{Kesimpulan}

Peristiwa G30S/PKI dipandang oleh TNIAD sebagai suatu peristiwa yang menginjakinjak harga diri dan merusak citra bangsa, khususnya TNI-AD sebagai satuan keamanan negara. Memori kolektif yang tertanam dalam tubuh TNI-AD adalah bahwa peristiwa G30S/ PKI merupakan bentuk-bentuk perlawanan komunis terhadap negara. Hal tersebut terus digaungkan kemasyarakat dari generasi ke generasi, Memori kolektif ini menjadi dasar untuk mengonstruksi citra PKI sebagai oposisi negara.
Akibat dari memori kolektif yang terbentuk, baik di tingkat prajurit TNI-AD, maupun pada masyarakat sipil, upaya pembersihan dan pemberantasan terhadap simpatisan PKI oleh Militer seolah-olah dibenarkan oleh rakyat Indonesia untuk menghilangkan jejak PKI dan komunis sebagai musuh negara dan mengancam kedaulatan dan ideologi negara.

Upaya pemerintah untuk menumpas PKI dilakukan melalui berbagai strategi, teknik dan wacana-wacana pendisiplinan dan penyeragaman pemahaman (dalam bentuk pembangunan Monumen Pancasila Sakti, penuntasan PKI pasca G30S/PKI, dalam pendidikan TNI mulai dari perekrutan TNI hingga doktrindoktrin dalam proses pendidikan TNI). Berbagai upaya ini dilakukan untuk menyatukan pemahaman dan menormalisasikan wacana antikomunis di Indonesia.

\section{Daftar Pustaka}

Bastian, Radis. 2013. Tokoh-Tokoh Gelap: Yang Terlupakan dalam Peristiwa G30S. Jogjakarta: Palapa.

Elson, Robert E., 2008. Suharto: A Political Bioghraphy. Cambridge University Press

Fic, Victor M. 2004. Kudeta 1 Oktober 1965: Sebuah Studi tentang Konspirasi. Jakarta: Yayasan Obor Indonesia.

Foucault, Michael. 1979. Discipline and Punish: The Birth of the Prison. Diterjemahkan oleh A. Sheridan. New York: Vintage Books.

Foucault, Michael. 1984. Power/Knowledge: Selected Interview and Other Writings 1972-1977. Diterjemahkan oleh C. Gordon. New York: Pantheon.

Herlambang, Wijaya. 2013. Kekerasan Budaya Pasca 1965: Bagaimana Orde Baru Melegitimasi Anti-Komunisme Melalui Seni dan Sastra. Jakarta: Marjin Kiri.

Lampiran Peraturan Panglima TNI. 2010. Jakarta: Markas Besar TNI.

Moehkardi. 1981. Pendidikan dan Pembentukan Perwira TNI-AD. Jakarta: PT. Inaltu.

Olick, Jeffrey K., 1999. Collective Memory: The Two Cultures. Sociological Theory, 17(3), November, 333-348. 
Roosa, John. 2008. Dalih Pembunuhan Massal Gerakan 30 September dan Kudeta Suharto. Jakarta: Hasta Mitra.

Sejarah TNI Jilid III (1960-1965). 2000. Jakarta: Markas Besar TNI dan Pusat Sejarah dan Tradisi TNI.

Soemarmi, Amiek; Prihatin, Eko Sabar; \& Hasyim, Asy'ary. 2001. Suksesi Presiden: Studi Tentang Pengaturan Hukum dan Pola Pergantian Jabatan Presiden di Indonesia. Laporan Penelitian. Semarang: Fakultas Hukum, Universitas Diponegoro.
Sucipto, Herman Dwi. 2013. Kontroversi G30S: Antara Fakta dan Rekayasa. Jogjakarta: Palapa.

Wieringa, Saskia Eleonora. 2010. Penghancuran Geran Perempuan: Politik Seksual di Indonesia Pasca Kejatuhan PKI. Jogjakarta: Galang press.

Zulkifli, Arif \& Dhyatmika, Wahyu., 2012. Tokoh Militer: Sarwo Edhie dan Misteri 1965. Seri Buku Tempo. Jakarta: PT. Gramedia. 